\title{
地区特性の違いに着目した 道路インフラ維持更新コストに関する研究
}

\author{
松中 亮治 1 - 大庭 哲治 $2 \cdot$ 中川 大 $^{3}$ - 岡本 真輝 4 - \\ 米山一幸 5 ・田中 博一6 \\ 1正会員 京都大学准教授 大学院工学研究科（广615-8530 京都府京都市西京区京都大学桂） \\ E-mail: matsu@urban.kuciv.kyoto-u.ac.jp \\ 2正会員 京都大学助教 大学院工学研究科（干 615-8530 京都府京都市西京区京都大学桂） \\ E-mail: tetsu@urban.kuciv.kyoto-u.ac.jp \\ 3正会員 京都大学教授 大学院工学研究科（干615-8530 京都府京都市西京区京都大学桂） \\ E-mail:nakagawa@urban.kuciv.kyoto-u.ac.jp \\ 4学生会員 京都大学大学院工学研究科（干615-8530 京都府京都市西京区京都大学桂） \\ E-mail: m-okamoto@urban.kuciv.kyoto-u.ac.jp \\ 5 正会員 清水建設株式会社技術研究所社会システム技術センター（†135-8530 東京都江東区越中島） \\ E-mail: k.yone@shimz.co.jp \\ 6正会員 清水建設株式会社技術研究所社会システム技術センター（テ135-8530 東京都江東区越中島） \\ E-mail: hirokazu.tanaka@shimz.co.jp
}

\begin{abstract}
近年，コンパクトなまちづくりが注目されており，都市のコンパクト化の評価に際しては，地区特性と インフラ維持更新コストとの関係を定量的に示すことが重要である. 本研究では, 全国の3次メッシュを 地区特性の違いにより分類し，道路インフラを対象に，地区特性とインフラ維持更新コストとの関係を分 析した。その結果，人口あたり道路インフラ維持更新コストは地区特性の違いにより最大 16.7 倍の差があ ることを明らかにした。さらに，自然増減のみを考慮した場合と人口がコンパクトに集積した場合の，地 区特性による分類ごとの人口割合を用いて将来の道路インフラ維持更新コストを推計した結果, 人口がコ

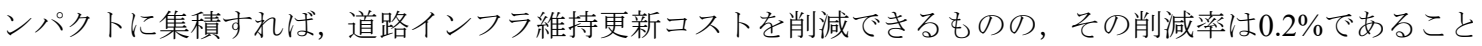
を明らかにした。
\end{abstract}

Key Words : road infrastructure, maintenance and renewal cost, area characteristics

\section{1. 背景と目的}

高度経済成長期以降，公共交通が不便な地域において も自動車を利用すれば不自由なく生活できる上，役場や 病院などの郊外部への移転も影響して，人口は低密度広 範囲に拡散して分布し，ますます都心の中心性を失うと いう悪循環が生じている，低密度広範囲に拡散した人口 分布では，道路，電気，ガス，水道や公共施設といった 各種インフラ設備もより広範囲に整備せざるを得ないこ とを意味している．近年ではコンパクトなまちづくりが 注目され，都市の公共交通を中心としたコンパクト化の 促進によって，既存インフラを有効活用できる上に，新 たに整備するインフラ量を必要最低限に抑えることがで
きると期待される.しかしながら，コンパクトなまちづ くりを積極的に取り組んでいるのはごく一部の都市に限 られており，都市のコンパクト化の評価を定量的に明ら かにすることが重要であると考えられる.

そこで本研究では，道路インフラを対象に，全国の3 次メッシュを地区特性の違いにより60に分類し, 地区特 性とインフラ維持更新コストとの関係を明らかにする.

また，平成22年度からの人口の自然増減のみを考慮した 場合と, 人口が都心部にコンパクトに集積した場合の, 地区特性による分類ごとの人口割合を用いて将来必要と なる道路インフラ維持更新コストを推計し，地区特性に よる分類ごとの人口割合と道路インフラ維持更新コスト の関係を明らかにすることを目的とする。 
具体的には2章で既往研究をレビューした上で本研究 の特徴を述べ，3章でデータベースを構築し，地区特性 によりメッシュを分類する. 続く4章で人口と道路イン フラ量との関係を示し，人口だけでなく，地区特性に着 目寸る必要性を述べる，そして5章では地区特性と幅員 別道路インフラ量との関係を分析した後, 地区特性と道 路インフラ維持更新コストとの関係を明らかにする. 6 章では自然増減のみを考慮した場合と人口がコンパクト に集積した場合の道路インフラ維持更新コストを，地区 特性を考慮して推計し, 都市のコンパクト化による道路 インフラ維持更新コスト削減額を定量的に算出している.

\section{2. 既往研究のレビューと本研究の特徵}

\section{(1) 既往研究のレビュー}

インフラ維持更新コストを対象にした主要な既往研究 として, 以下の5つが挙げられる.

佐藤・森本 ${ }^{1} の$ 研究では, 栃木県宇都宮市を対象に3次 メッシュを用いた分析を行っている. 保育施設, 小学校, 中学校, 公民館といった都市拠点施設は利用者数の指数 関数で, 道路橋梁, 下水道, 水道といった都市基盤施設 は人口密度の指数関数で単位面積あたり延長を算出し延 長あたり維持管理費を乗じて求めている. 将来において は将来人口を基に利用者数, 人口密度を求めて維持管理 費を推計している.

加知ら 2)の研究では, 新潟県上越市を対象に4次メッシ 二を用い，道路については幹線系のものを除いたのち， 市全体でのインフラ維持コストを道路台帳調查から得ら れた各道路区間の延長, 幅員, 面積等を考慮して配分し た上で, 経年変化しないものとしてインフラ維持コスト を推計している.

また, 加知ら 3)の研究では, 長野県飯田市を対象に4次 メッシュを用い，家屋の撤退・再結集を考え，撤退した 家屋数, 再結集した家屋数に応じて削減可能な市街地維 持コスト, 新たに必要となる市街地維持コストを推計し ている. なお, 道路や下水道のネットワーク系インフラ については主要幹線は除去せず維持されるものとしてコ ストを推計している.

土屋・室町4)は日本全国を対象に3次メッシュを用い, 高速道路, 一般国道, 主要地方道, 都道府県道, 指定市 の一般市道以外の道路を対象として, その道路延長は将 来においても変わらないと仮定して, さらに，50人メ ッシュ未満のメッシュに対して道路維持管理費用を投じ ないものとして削減効果を推計している.

根市ら5゙は日本全国を対象に3次メッシュを用い，道路 維持管理費用を，人口密度を説明変数とした回帰式によ り道路延長を求めた後, 延長あたり維持管理費用原単位
を乗じて算出した上で, 将来においては50人メッシュ 未満のメッシュに対して維持管理費用を投じないものと して削減効果を推計している.

これらの研究は, いずれも, 特定の一地域のみについ て道路インフラ維持更新コストを推計したものや，人口 や家屋数のみによってインフラ量を推計したもの, 人口 の少ない地域に対してのインフラ維持更新を実施しない ことを仮定したものであり，全国的に地区特性について 着目して, 地区特性と道路延長との関係を分析し, 地区 特性の違いによる人口あたり道路インフラ量の違いを考 慮して将来の道路インフラ維持更新コストを推計したも のではない，地区特性に着目することにより，全国を網 羅的に把握できるとともに, その地域に適した将来の道 路インフラ量を仮定できるという利点がある.

\section{(2) 本研究の特幑}

以上の既往研究を踏まえて, 本研究の特徵としては, 以下の点が挙げられる.

・日本全国の3次メッシュを地区特性により分類し，そ の分類ごとに，人口と道路インフラ量・道路インフラ 維持更新コストとの関係を経年変化も含めて明らかに している点.

・将来において人口が少なくなった地域でも，一定水準 まで道路を整備すると仮定している点.

・全国を対象として人口がコンパクトに集積した場合の 道路インフラ維持更新コスト削減額を定量的に算出し ている点.

\section{3. 道路インフラ量と地区特性に関するデータベ 一スの構築とメッシュの分類}

\section{（1） 道路インフラ量と地区特性に関するデータベース の構築}

\section{a) メッシュ道路延長}

メッシュ道路延長には国土数值情報ダウンロードサー ビスのの「道路密度・道路延長メッシュデータ」昭和53 年度, 平成16年度, 平成22年度を用いる. 本研究では, 各年次で比較できるよう, 道路の幅員を「幅員 $13.0 \mathrm{~m}$ 以 上」「幅員 $5.5 \mathrm{~m}$ 以上 $13.0 \mathrm{~m}$ 未満」「幅員 $5.5 \mathrm{~m}$ 未満」の $3 つ$ に分類する．昭和 53 年度の「幅員 $11.0 \mathrm{~m}$ 以上」と平成 16 年度，平成22年度における「幅員 $13.0 \mathrm{~m}(11.0 \mathrm{~m})$ 以上」 は「幅員 $13.0 \mathrm{~m}$ 以上」に, 昭和 53 年度の「幅員 $5.5 \mathrm{~m}$ 以上 $11.0 \mathrm{~m}$ 未満」と平成 16 年度, 平成 22 年度の「幅員 $5.5 \mathrm{~m}$ 以 上 $13.0 \mathrm{~m}(11.0 \mathrm{~m})$ 未満」は「幅員 $5.5 \mathrm{~m}$ 以上 $13.0 \mathrm{~m}$ 未満」に 分類する.また, 「幅員 $5.5 \mathrm{~m}$ 未満」の道路はまとめて分 類する. なお, 国土数值情報では, 昭和 53 年度は幅員 $11.0 \mathrm{~m}$ で区切られ, 平成16年度, 平成22年度については 
幅員13.0mで区切られているが地形図の図式により $11.0 \mathrm{~m}$ に読み替えてデータが作成されており，13.0mで区切ら れた部分なのか否かは判別できない，そのため，本研究 では表記上，13.0mを区切りとする.

しかし, 国土数值情報のデータから得られた幅員ごと の延長と，各年次の道路統計年報》「表3 道路実延長内 訳の総括表」から得られた幅員ごとの延長に乘離が見ら れる. 国土数值情報のデータでは道路の総延長は昭和53 年度から平成16年度にかけて減少しているが，総道路延 長は道路統計年報同様，過去から増加してきたと考えら れるため, 道路統計年報の幅員ごとの道路延長に一致す るよう国土数值情報の各メッシュデータに補正值を乗じ た值をメッシュ道路延長とする，なお，道路統計年報で 「未改良」で「幅員 $5.5 \mathrm{~m}$ 以上」の道路延長は「幅員 $5.5 \mathrm{~m}$ 以上 $13.0 \mathrm{~m}$ 未満」に加え,「自動車交通不能区間」の道 路延長は「幅員 $5.5 \mathrm{~m}$ 末満」道路延長から差し引く.

b) メッシュ人ロ

本研究では, メッシュ道路延長の昭和53年度, 平成 16 年度, 平成22年度に対応して, 昭和55年度, 平成17年度, 平成22年度の地域メッシュ統計8を用い，各メッシュに 住む人口を「メッシュ人口」とする.

\section{c) メッシュの都市圏による分類}

本研究では，以下のように「メッシュの都市圈による 分類」を定義する. 社会資本整備審議会「都市再生ビジ ヨン」9が設定した88の都市圈域を，大都市圈と地方都 市圈に分類する。「大都市圈」は核都市が東京都，神奈 川県, 埼玉県, 千葉県, 愛知県, 岐阜県, 三重県, 大阪 府, 兵庫県, 京都府, 奈良県, 和歌山県にある都市圈と 平成22年現在に政令指定都市である市と特別区を核都市 に含む都市圈を合わせたものと定義する. それ以外の都 市圈域を「地方都市圈」に分類する．市区町村はそれぞ れの都市圈域により分類した後, 核都市か㧵かで分類す る. 以上の方法により，市区町村を「大都市圈核都市」， 「大都市圈周辺都市」, 「地方都市圈核都市」, 「地方 都市圈周辺都市」，「非都市圈」に分類する. メッシュ が属する市区町村はメッシュ内で最大の面積を持つ市区 町村とし, その市区町村の都市圈の分類を「メッシュの 都市圈による分類」とする.

d) メッシュ内の都市地域・用途地域・市街化調整区域 面積割合

本研究では，国土数值情報ダウンロードサービスより， 平成23年度の「都市地域データ」, 「用途地域データ」 を用い, UTM直交座標系で陸地面積あたりの都市地域 面積割合，用途地域面積割合，市街化調整区域割合をそ れぞれ算出する.

\section{e) 最寄り駅からの距離}

本研究では, 国土数值情報ダウンロードサービスの 「鉄道データ」平成 25 年度を用い, メッシュの重心から

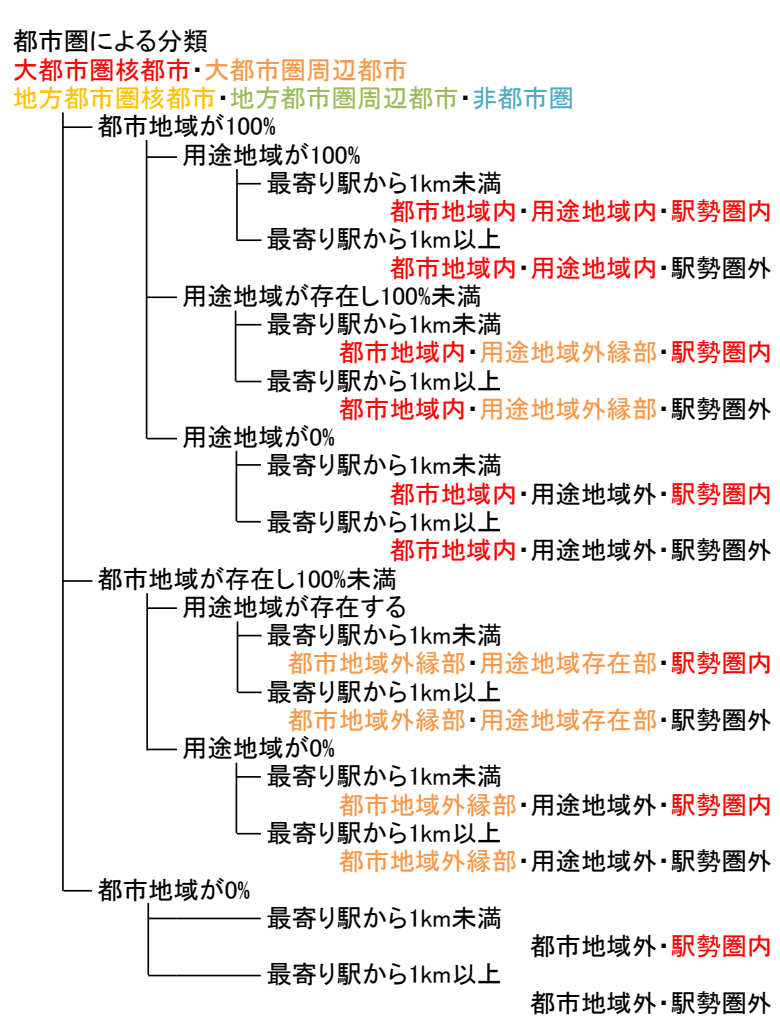

図-1 地区特性による分類

最寄りの駅ラインデータの中点までの距離をUTM直交 座標系により算出し，それを「最寄り駅からの距離」と する.

\section{（2）地区特性によるメッシュの分類}

前節で構築したデータベースを基に，以下のようにメ ッシュを地区特性により分類する. まず, 都市圈により メッシュを分類した後, 図-1に示すようにメッシュを分 類する。「都市地域が $100 \%$ には，陸地面積の全てが 都市地域であるメッシュを，「都市地域が存在し100\% 未満」には, 都市地域と都市地域外を含んでいるメッシ ユを，「都市地域が $0 \% 」 に は$ 都市地域を含んでいない メッシュを分類する. 用途地域について同様に「用途地 域が $100 \%$ ，「用途地域が存在し $100 \%$ 未満」，「用途 地域が $0 \%$ 」および「用途地域が存在する」に分類する. 「最寄り駅からの距離」が $1 \mathrm{~km}$ 未満の区域を駅勢圈とし, 最寄り駅から $1 \mathrm{~km}$ 未満の位置にあるメッシュを駅勢圈内, $1 \mathrm{~km}$ 以上の位置にあるメッシュを駅勢圏外とする.

\section{（3）道路インフラ維持更新コスト原単位の推定}

国土数值情報の道路延長データでは, 道路種別ごとの 道路延長は与えられておらず, 道路幅員ごとの道路延長 が与えられている，そのため, 道路幅員ごとの道路イン フラ維持更新コストを算出する必要がある. そのため, 本研究では幅員ごと道路インフラ維持更新コスト原単位 を以下のように推定する. 
同じ幅員の道路でも種別によって単位延長あたり道路 インフラ維持更新コスト原単位は異なると考えられる. 道路種別ごとの道路インフラ維持更新コスト原単位の比 は，「道路投資の評価に関する指針（案）」10)にある 「表3-3-3 道路種別ごとの年間維持管理費（参考）」の 維持費, 修繥費, 交通安全費を合計したものを用いる. つまり，高速自動車国道，一般国道（指定区間），一般 国道（指定区間外），主要地方道（含む主要市道），一 般都道府県道, 市町村道の道路インフラ維持更新コスト 原単位比をそれぞれ，86:42:20:10:6:1とする.

各種別, 各幅員の道路延長は「道路統計年報2012」よ り求める. 平成22年度の実際の道路インフラ維持更新コ ス卜は道路統計年報2012の「平成22年度道路・都市計画 街路事業費総括表」の橋梁補修, 舗装補修, その他修繕, 維持，各高速道路会社の「事業費（実績額）」の修繥費， 「道路事業費（その他事業I）」「道路事業費（その他 事業II）」「失業対策事業費」の維持修繥を合計した 17,061億円を用いる.

道路種別ごとの維持更新コスト原単位比，道路種別ご との道路延長を乗じたものを足し合わせ，実際の道路イ ンフラ維持更新コストと比較することで, 平成22年度の 道路種別ごとの道路インフラ維持更新コストを算出する

$$
\begin{aligned}
& \sum_{i}\left(c_{i} \sum_{j} l_{i j}\right)=C_{a l l} \\
& C_{i}=c_{i} \sum_{j} l_{i j}
\end{aligned}
$$

$i:$ 道路種別

$j:$ 道路幅員

$c_{i}$ : 道路種別ごとの道路インフラ維持更新コスト原単位

（道路種別ごと原単位比を用いる。）

$l_{i j}:$ 道路種別ごと道路幅員ごとの道路延長

$C_{\text {all }}:$ 総道路インフラ維持更新コスト

$C_{i}:$ 道路種別ごとの道路インフラ維持更新コスト

道路幅員ごとの道路インフラ維持更新コスト原単位の 比を幅員 $13.0 \mathrm{~m}$ 以上，幅員 $5.5 \mathrm{~m}$ 以上 $13.0 \mathrm{~m}$ 未満，幅員 $5.5 \mathrm{~m}$ 未満の順に $3: 2: 1$ とする. これは, 道路幅員を順に $15.0 \mathrm{~m} ， 10.0 \mathrm{~m} ， 5.0 \mathrm{~m}$ 仮定しているためである。 それぞ れの道路種別について, 道路種別ごと道路幅員ごとの道 路インフラ維持更新コスト原単位を求める.

$$
\sum_{j} c_{i j} l_{i j}=C_{i}
$$

$c_{i j}$ : 道路種別ごと道路幅員ごとの道路インフラ維持更新 コスト原単位（道路幅員ごと原単位比を用いる.）

次に，道路幅員ごとに道路インフラ維持更新コストを 算出し, その幅員の道路延長で除することで道路幅員ご との道路インフラ維持更新コスト原単位を設定する.

$$
\begin{aligned}
& C_{j}=\sum_{i} c_{i j} l_{i j} \\
& c_{j}=C_{j} / \sum_{i} l_{i j}
\end{aligned}
$$

$C_{j}$ : 道路幅員ごとの道路インフラ維持更新コスト

$c_{j}$ : 道路幅員ごとの道路インフラ維持更新コスト原単位

以上の方法により算出した道路インフラ維持更新コス 卜原単位を表-1に示寸.ここで求めた原単位を用いてメ ッシュごとに道路インフラ維持更新コストを計算する.

\section{4. 人口と道路インフラ量との関係}

日本全国のメッシュについて，平成22年度のメッシュ 人口とメッシュ道路延長との関係を幅員別に図-2から図 -4に示す．幅員 $13.0 \mathrm{~m}$ 以上および幅員 $5.5 \mathrm{~m}$ 以上 $13.0 \mathrm{~m}$ 未満 においては, 線形近似の決定係数が大きくなく, メッシ ユ人口とメッシュ道路延長に相関があるとは言えない. 幅員 $5.5 \mathrm{~m}$ 未満の道路においては, 線形近似の決定係数が 0.6155 と他の幅員と比較して大きく, メッシュ人口とメ ッシュ道路延長との間には相関が見られる.

また，人口が0であるメッシュを除いた人口あたり幅 員 $5.5 \mathrm{~m}$ 未満道路延長は，大都市圈・地方都市圈・非都市 圈間および，大都市圈の核都市・周辺都市間，地方都市 圈の核都市・周辺都市間で平均值に有意差があり, 大都 市圈ほど，核都市ほど，人口あたり道路延長は小さい. このように人口だけでなく, 地区特性の違いによって人 口と道路延長との関係が異なっていることがわかる.

表-1 道路インフラ維持更新コスト原単位

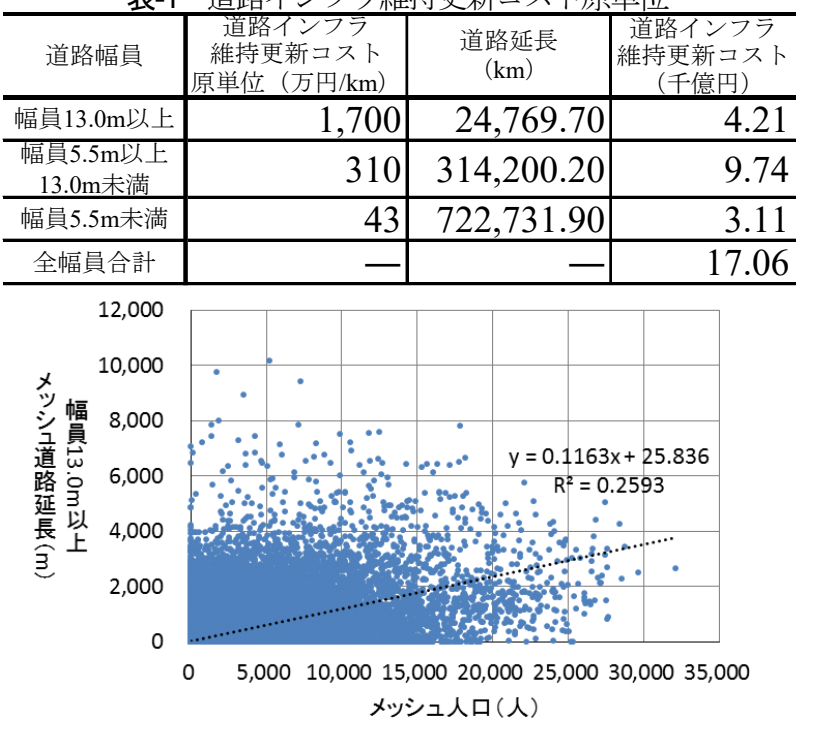

図-2 人口と道路延長との関係（幅員 $13.0 \mathrm{~m}$ 以上） 


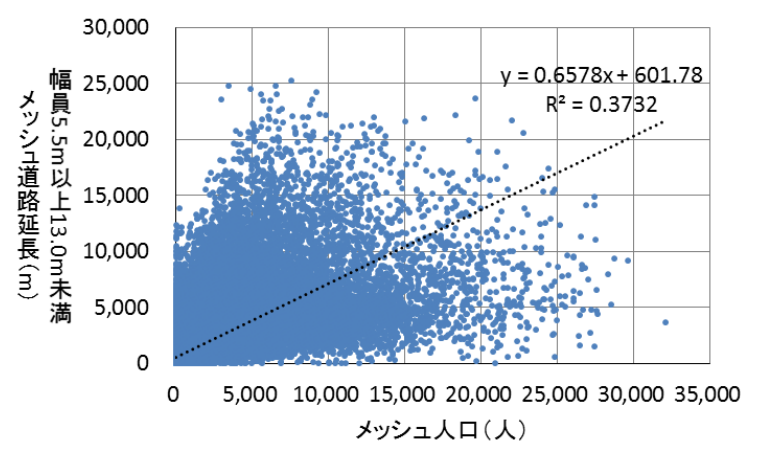

図-3 人口と道路延長との関係（幅員 $5.5 \mathrm{~m} \sim 13.0 \mathrm{~m}$ )

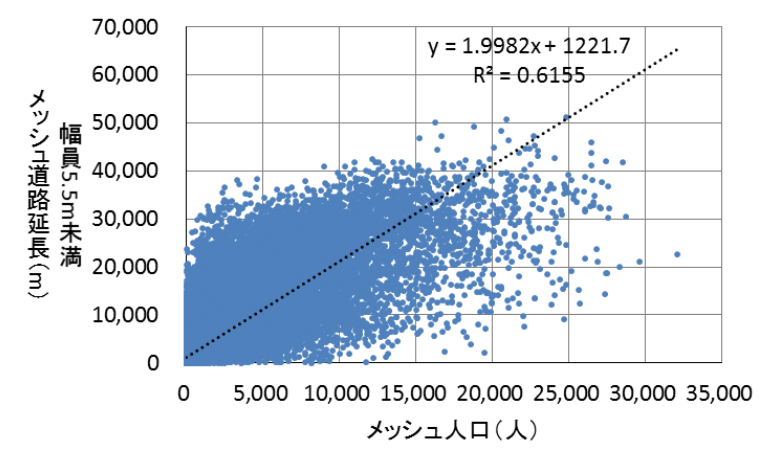

図-4 人口と道路延長との関係（幅員 $5.5 \mathrm{~m}$ 未満）

\section{5. 地区特性と道路インフラ量および道路インフ ラ維持更新コストとの関係}

\section{（1）地区特性と道路インフラ量との関係}

幅員 $5.5 \mathrm{~m}$ 未満の道路について，地区特性による分類ご との人口あたり道路延長を図-5に示寸．用途地域が存在 寸る分類の駅勢圈内, 外, 都市地域外や用途地域外の駅 勢圈内，外の順に小さい傾向にある．たとえ人口規模が 同程度の地区であっても，属する都市圈や駅勢圈内外の 違いといった地区特性により，分類間で最大 23.2 倍の差 があることがわかる.

幅員 $13.0 \mathrm{~m}$ 以上の道路について，平成16年度から平成 22年度にかけての地区特性による 60 分類の人口の変化率 と道路延長の変化率との関係を図-6に，幅員 $5.5 \mathrm{~m}$ 以上 $13.0 \mathrm{~m}$ 未満の道路について，人口の変化率と道路延長の 変化率との関係を昭和53年度から平成16年度にかけては 図-7に，平成16年度から平成22年度にかけては図-8に示 す．ここで，図中ので示した「用途地域が存在」する分 類は，「用途地域内」「用途地域外縁部」「用途地域存 在部」を，図中一で示した「都市地域外・用途地域外」 の分類は,「用途地域外」「都市地域外」を示寸.さら に色によって，「大都市圈核都市」「大都市圈周辺都 市」「地方都市圈核都市」「地方都市圈周辺都市」「非 都市圈」に分類している.

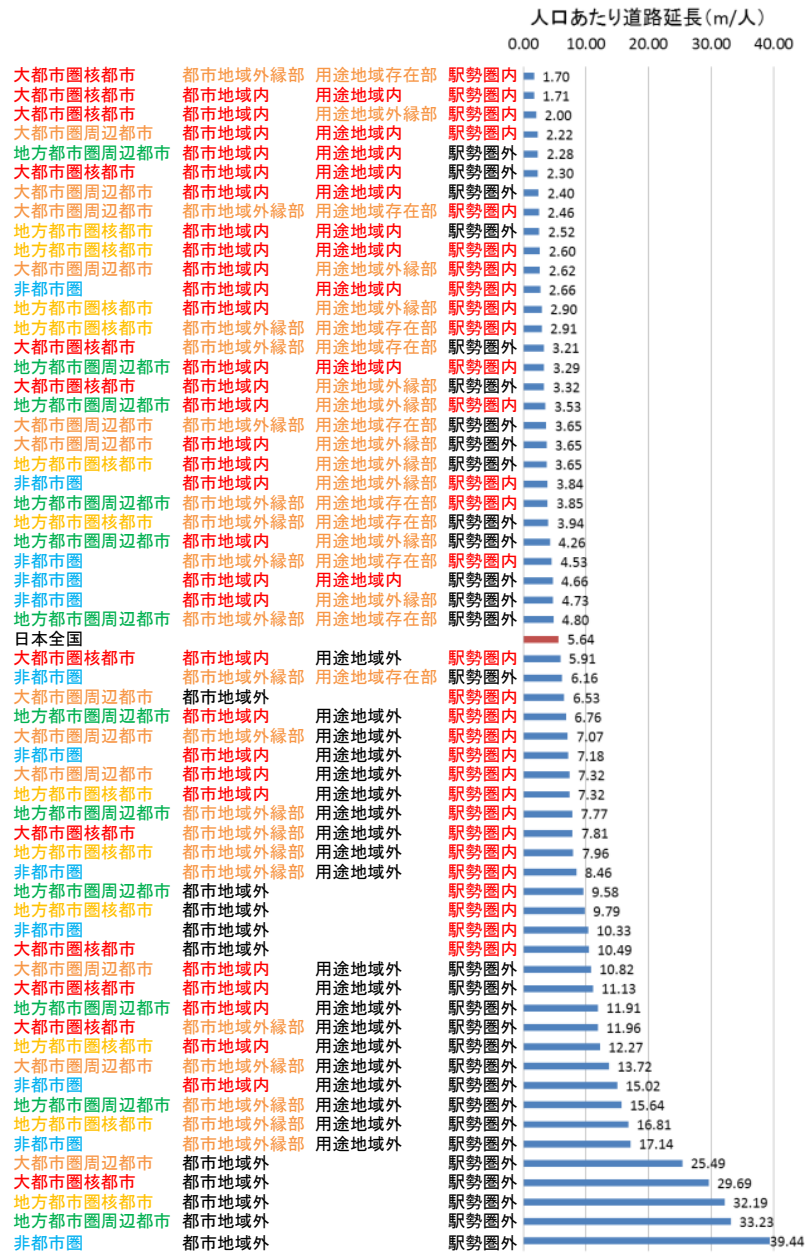

図-5 人口あたり幅員 $5.5 \mathrm{~m}$ 未満道路延長

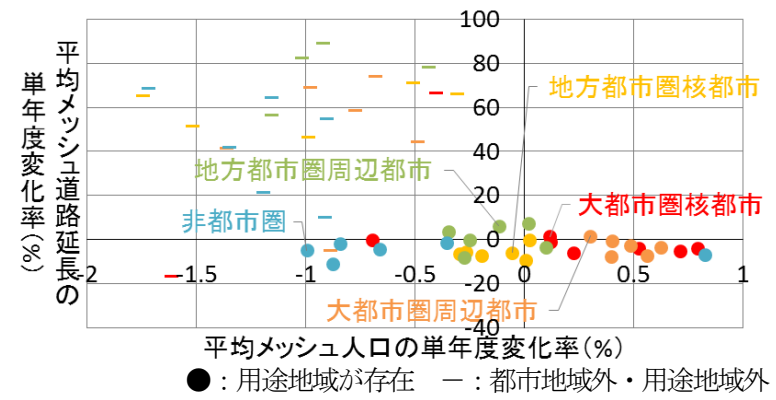

図-6 人口と道路延長の変化率の関係（H16-H22，幅員 $13.0 \mathrm{~m}$ 以上)

幅員 $13.0 \mathrm{~m}$ 以上の道路は平成 16 年度から平成22年度に かけて都市地域外や用途地域外の分類で道路延長の増加 率が極めて大きくなっている.

幅員 $5.5 \mathrm{~m}$ 以上 $13.0 \mathrm{~m}$ 未満の道路は昭和 53 年度から平成 16年度にかけては大都市圈周辺都市，地方都市圈周辺都 市，非都市圈においては人口の増加率，都市地域，用途 地域の有無に関わらず1〜2\%の増加率であるが，大都市 圈核都市や地方都市圈核都市の用途地域が存在寸る分類 では増加率が大きい. 平成16年度から平成22年度にかけ てはこれまでに整備が進んだ大都市圈核都市や地方都市 圏核都市をはじめ，用途地域が存在する分類では道路延 
長の増加率は抑えられている. 一方, まだ整備の余地が ある都市地域外や用途地域外の分類では人口が減少して いても道路延長増加率は大きくなっている.

幅員 $5.5 \mathrm{~m}$ 未満の道路について, 地区特性による60分類 の人口の変化率と道路延長の変化率との関係を昭和 53 年 度から平成16年度にかけては図-9に，平成16年度から平 成22年度にかけては図-10に示す。昭和53年度から平成 16年度にかけて道路延長は, 用途地域が存在する分類で は人口の変化率に関わらず3\%程度増加し, 都市地域外 や用途地域外の分類ではあまり変化がない，平成16年度 から平成22年度にかけては大都市圈核都市，大都市圈周 辺都市，地方都市圈核都市の用途地域が存在する分類に おいて道路延長の増加率は大きく, 近年もなお整備が進 んでいることが分かる，一方，都市地域外や用途地域外 の分類や, 地方都市圈周辺都市, 非都市圈の分類の多く で人口が減少しており，その分類において道路延長は $1 \%$ 程度減少している.

このように，3次メッシュ単位で人口と道路延長との 関係を分析すると，幅員 $13.0 \mathrm{~m}$ 以上，幅員 $5.5 \mathrm{~m}$ 以上 $13.0 \mathrm{~m}$ 未満の道路については，ネットワークを構成する上で整 備される道路が多いため, 人口の増減と道路インフラ量 の増減との相関が小さく, 現状では人口が減少している 分類で道路延長が増加している. 一方, 幅員 $5.5 \mathrm{~m}$ 未満の 道路については, 人口が増加している分類で道路延長が 増加しており, 人口が減少している分類で道路延長の増 加は見られない.このため, 幅員 $5.5 \mathrm{~m}$ 未満の道路につい て，コンパクト化の効果は大きいと考えられる.

また，幅員 $5.5 \mathrm{~m}$ 末満の道路について，平成16年度から 平成22年度にかけての道路延長単年度変化率が最も大き い「大都市圈周辺都市・都市地域内 ・用途地域内 - 駅勢 圈内」において, 平成16年度の人口あたり道路延長がそ の分類全体の人口あたり道路延長よりも短いメッシュと 長いメッシュに分類し, 平成22年度にかけての道路延長 単年度変化率で平均值の差の検定を行った. その結果, 人口あたり道路延長が，分類全体より短いメッシュの単 年度変化率の平均は $17.9 \%$, 分類全体より長いメッシュ の平均は $3.5 \%$ で， $0.01 \%$ 有意で単年度変化率は人口あた り道路延長が分類全体より短いメッシュのほうが高いこ とがわかった. このように, 道路は, 現在の人口あたり 道路延長が分類全体の人口あたり道路延長より短いメッ シュで増加すると考えられる。

\section{（2）地区特性と道路インフラ維持更新コストとの関係}

地区特性による分類別の人口あたり道路インフラ維持 更新コストを少ない順に並べたものを図-11に示寸.

用途地域がある分類で人口あたり維持更新コストが小 さく，都市地域外や用途地域外の分類で大きくなる．ま た，用途地域が存在するすべての分類で，大都市圈核都

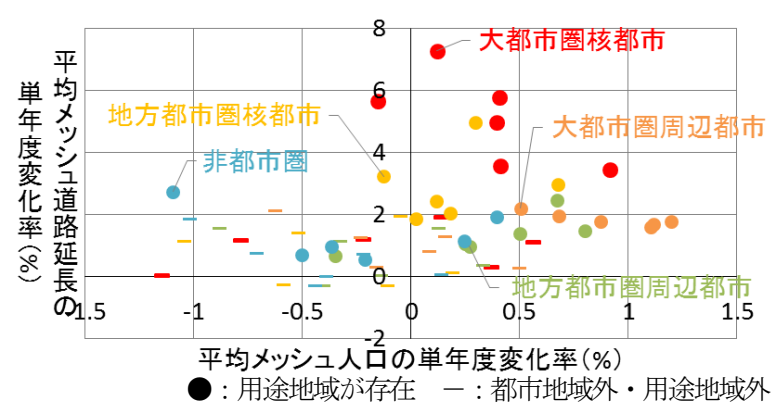

図-7 人口と道路延長の変化率の関係 (S53-H16, 幅員 $5.5 \mathrm{~m}$ 以上 $13.0 \mathrm{~m}$ 末満)

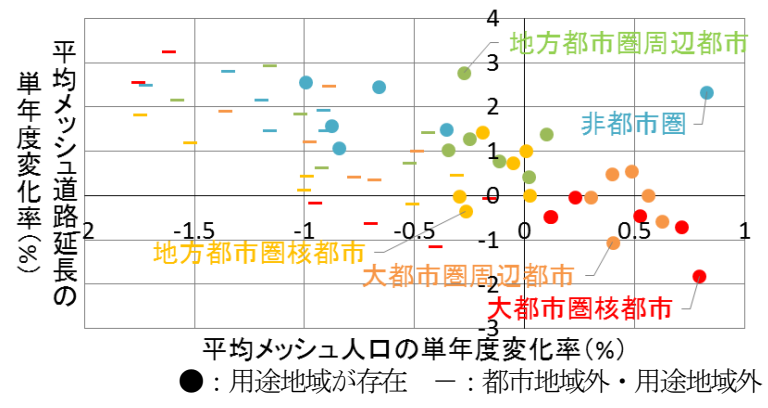

図-8 人口と道路延長の変化率の関係 (H16-H22, 幅員 $5.5 \mathrm{~m}$ 以上 $13.0 \mathrm{~m}$ 末満 $)$

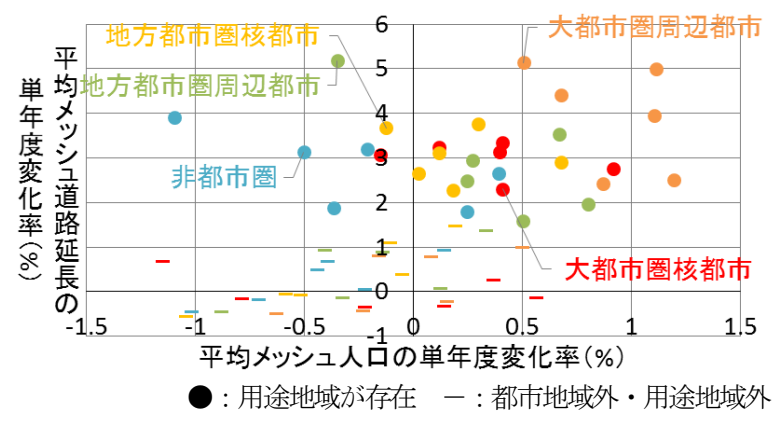

図-9人口と道路延長の変化率の関係 (S53-H16, 幅員 $5.5 \mathrm{~m}$ 未満)

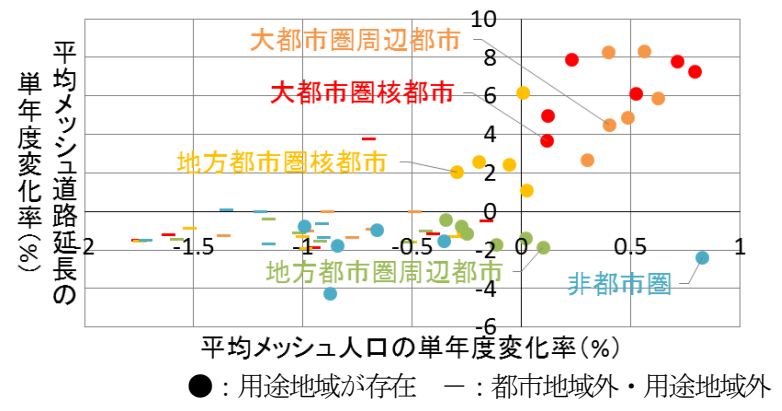

図-10 人口と道路延長の変化率の関係 (H16-H22, 幅員 $5.5 \mathrm{~m}$ 未満)

市よりも大都市圈周辺都市のほうが小さい. 最小である 「大都市圈周辺都市・都市地域内・用途地域内・駅勢圈 内」と最大である「非都市圏・都市地域外・駅勢圈外」 
では6万8千円，16.7倍の差がある．また，それぞれの都 市圈による分類の中での最小の分類と最大の分類との差 は，大都市圈核都市で7.3倍，大都市圈周辺都市で10.9倍， 地方都市圈核都市で7.7倍，地方都市圈周辺都市で6.8倍， 非都市圈で7.0倍であり, 大都市圈周辺都市において地 区特性による分類で人口あたり維持更新コストに差があ ることが分かる．また，大都市圈周辺都市の用途地域が 存在する分類では人口あたり道路インフラ維持更新コス トが小さく, 他の都市圈による分類と比較して, 道路イ ンフラは人口比でみると少ない地域であるといえる.

地区特性による60分類の人口の変化率と道路インフラ 維持更新コストの変化率との関係を昭和53年度から平成 16年度にかけては図-12に，平成16年度から平成22年度 にかけては図-13に示す。

昭和53年度から平成16年度にかけて，大都市圈核都市， 大都市圈周辺都市，地方都市圈核都市の用途地域が存在 する分類で道路インフラ維持更新コストの変化率が大き く, 都市地域外や用途地域外の分類で変化率は小さい.

平成16年度から平成22年度にかけては，用途地域が存 在する分類で道路インフラ維持更新コストは変化率が小 さく, 減少している分類もある. 都市地域外や用途地域 外の分類では昭和 53 年度から平成16年度にかけてより変 化率が増加している. これは, 維持更新コスト原単位の 大きい幅員 $13.0 \mathrm{~m}$ 以上，幅員 $5.5 \mathrm{~m}$ 以上 $13.0 \mathrm{~m}$ 未満の道路が 都市地域外や用途地域外の分類で顕著に増加しているこ とが要因であると考えられる.

\section{(3) 本章のまとめ}

本章では, 地区特性と道路インフラ量および道路イン フラ維持更新コストとの関係を明らかにした。

道路インフラ量に関しては, 3次メッシュ単位で人口 と道路延長との関係を分析した結果, 幅員 $5.5 \mathrm{~m}$ 末満の道 路では平成16年度から平成22年度にかけて大都市圈核都 市，大都市圈周辺都市，地方都市圈核都市の用途地域が 存在する分類で道路延長の増加率が大きく, 都市地域外 や用途地域外の分類や，地方都市圈周辺都市，非都市圈 の分類の多くで人口が減少しており，これらの分類のほ とんどで道路延長は増加していないことを明らかにした。 また，人口あたり道路インフラ維持更新コストに関し ては, 用途地域が存在する分類で小さく, 都市地域外や 用途地域外の分類で大きく，地区特性による60分類間で は最大6万 $8 千 円 ， 16.7$ 倍の差があることを示した．平成 16年度から平成22年度にかけては幅員の大きい道路延長 が増加している都市地域外や用途地域外の分類で増加し ており，用途地域が存在する分類で増加率は小さく，減 少している分類も存在することを明らかにした.

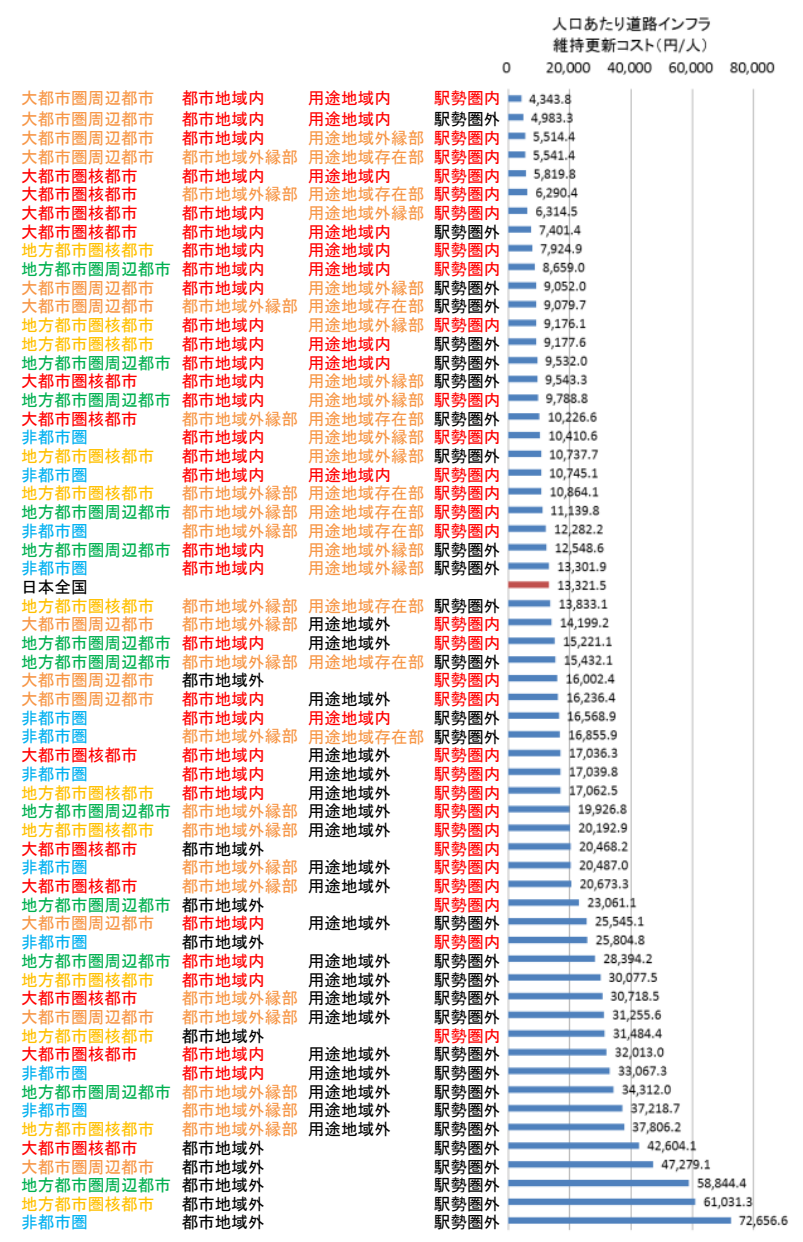

図-11 人口あたり道路インフラ維持更新コスト

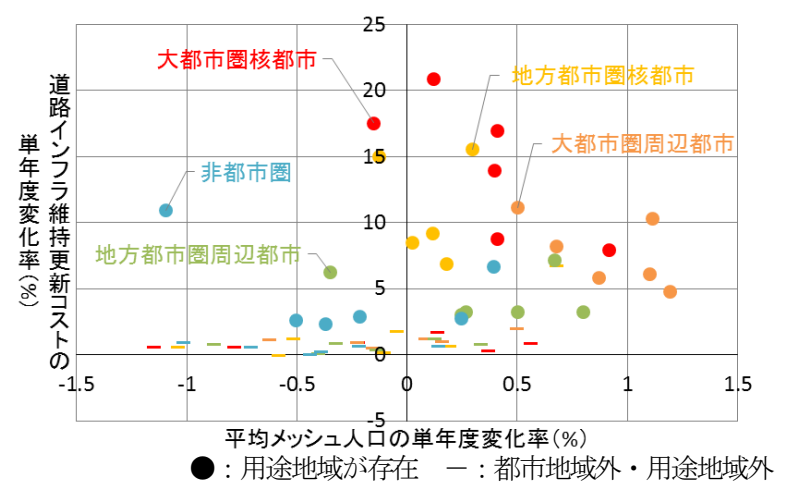

図-12人口と道路インフラ維持更新コストの変化率の関係 (S53-H16)

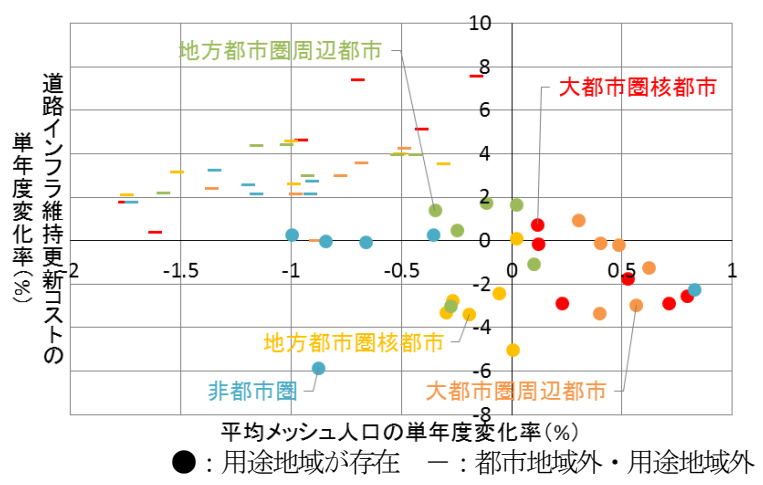

図-13人口と道路インフラ維持更新コストの変化率の関係 (H16-H22) 


\section{6. 将来の人口分布と道路インフラ維持更新コス トとの関係}

\section{(1) 将来の人口分布シナリオの設定}

本研究では，自然増減のみを考慮した場合と人口がコ ンパクトに集積した場合の，地区特性による分類ごとの 人口割合を, 以下の人口分布シナリオとして設定する.

\section{a) 自然増減のみを考慮した人口分布（Case1）}

国土数值情報ダウンロードサービスの「将来人口推計 メッシュ」データのうち，「メッシュ別2050年度総人口 （補正あり）」を用いる。このデータは2010年度の人口 分布でその後の社会増減を考慮せず，自然増減のみを考 慮した2050年度人口分布である.

\section{b) 人口が集積した場合の人口分布（Case2）}

都市のコンパクト化施策の結果として，Case1を基準 に人口が郊外部から都心部に集積した場合の人口分布を 設定する．都市圈による分類を越える移動は起こらない と仮定し，各都市圈における都市地域による分類の人口 割合を，都市地域内はCase1の5\%増，都市地域外縁部は Case1の5\%減，都市地域外はCase1 と等しいものとして人 口を移動させる，そして，都市地域内における人口割合 を用途地域内はCase1の5\%増, 用途地域外縁部はCase1の 5\%減，用途地域外はCase1 と等しく，都市地域外縁部の 用途地域による分類における人口割合はCase1 と等しい と仮定し人口を移動させる．さらに，用途地域による分 類における人口割合を駅勢圈内は $5 \%$ 増，駅勢圈外は $5 \%$ 減とする.

\section{（2）人口分布と道路インフラ維持更新コストとの関係}

道路インフラ維持更新コストは以下のように推計する。 このとき，4(1)に示したように，人口をコンパクトに集 積したときの効果は, 幅員 $5.5 \mathrm{~m}$ 未満の道路において大き いと考えられる. そのため, 将来の道路インフラ量は, 幅員 $13.0 \mathrm{~m}$ 以上，幅員 $5.5 \mathrm{~m}$ 以上 $13.0 \mathrm{~m}$ 未満の道路に関して は，平成22年度から変化せず，幅員 $5.5 \mathrm{~m}$ 未満の道路に関 しては，人口分布により変化すると仮定する.

平成22年度の各地区特性による分類での人口あたり道 路延長をその分類内のメッシュの将来人口に乗じ，それ を「必要道路延長」とする. 平成22年度での道路延長が 必要道路延長よりも小さい場合, 必要道路延長まで新た に整備されるものとする。，一方，平成22年度道路延長が 必要道路延長よりも大きい場合, 既存の道路インフラを 除去する，あるいは維持更新を実施しないということは 現実的ではないと考えられるため, 平成22年度道路延長 を将来のメッシュ道路延長として用いることとする。 そ して，3(3)の表-1に示した道路インフラ維持更新コスト 原単位を乗じて将来の道路インフラ維持更新コストを推 計する.
表-2 各 Caseの道路インフラ維持更新コスト

\begin{tabular}{|c|c|c|c|c|}
\hline \multirow[t]{2}{*}{ 都市圏による分類 } & \multicolumn{2}{|c|}{$\begin{array}{c}\text { 自然増減のみを考慮 } \\
\text { (Case 1) }\end{array}$} & \multicolumn{2}{|c|}{$\begin{array}{c}\text { コンパクトに集積 } \\
\text { (Case2) }\end{array}$} \\
\hline & 幅員5.5m末満 & 全幅員合計 & 幅員 $5.5 \mathrm{~m}$ 未満 & 全幅員合計 \\
\hline 大都市圏核都市 & $4,364,320$ & $26,993,421$ & $\begin{array}{r}4,341,087 \\
0.53\end{array}$ & $\begin{array}{r}26,970,188 \\
0.09\end{array}$ \\
\hline 大都市圏周辺都市 & $9,351,647$ & $43,619,144$ & $\begin{array}{r}9,281,261 \\
0.75 \\
\end{array}$ & $\begin{array}{r}43,548,758 \\
0.16 \\
\end{array}$ \\
\hline 地方都市圏核都市 & $4,949,275$ & $27,579,940$ & $\begin{array}{r}4,895,721 \\
1.08 \\
\end{array}$ & $\begin{array}{r}27,526,386 \\
0.19 \\
\end{array}$ \\
\hline 地方都市圏周辺都市 & $8,431,900$ & $38,971,358$ & $\begin{array}{r}8,322,251 \\
1.3 \\
\end{array}$ & $\begin{array}{r}38,861,708 \\
0.28 \\
\end{array}$ \\
\hline 非都市圏 & $9,138,156$ & $38,581,993$ & $\begin{array}{r}9,027,424 \\
1.21\end{array}$ & $\begin{array}{r}38,471,261 \\
0.29 \\
\end{array}$ \\
\hline 全国 & $36,235,298$ & $175,745,856$ & $\begin{array}{r}35,867,743 \\
1.01 \\
\end{array}$ & $\begin{array}{r}175,378,301 \\
0.21 \\
\end{array}$ \\
\hline
\end{tabular}

表-3 人口の少ないメッシュで維持更新を実施しないとした 場合の道路インフラ維持更新コスト

\begin{tabular}{|c|c|c|c|}
\hline 都市圏による分類 & $\begin{array}{c}\text { コンパクトに集積 } \\
\text { (Case2) }\end{array}$ & \begin{tabular}{|c|} 
メッシュ人ロ0人で \\
維持更新を実施しないい
\end{tabular} & $\begin{array}{l}\text { メッシュ人口10人未満で } \\
\text { 維持更新を実施しいい }\end{array}$ \\
\hline 大都市圏核都市 & $26,970,188$ & $\begin{array}{r}26,782,856 \\
0.69\end{array}$ & $\begin{array}{r}24,770,481 \\
8.16\end{array}$ \\
\hline 大都市圏周辺都市 & $43,548,758$ & $\begin{array}{r}42,992,431 \\
1.28\end{array}$ & $\begin{array}{r}36,711,367 \\
15.7\end{array}$ \\
\hline 地方都市圏核都市 & $27,526,386$ & $\begin{array}{r}26,961,007 \\
2.05\end{array}$ & $\begin{array}{r}23,823,974 \\
13.45\end{array}$ \\
\hline 地方都市圏周辺都市 & $38,861,708$ & $\begin{array}{r}37,338,455 \\
3.92\end{array}$ & $\begin{array}{r}31,657,136 \\
18.54\end{array}$ \\
\hline 非都市圏 & $38,471,261$ & $\begin{array}{r}35,575,187 \\
7.53\end{array}$ & $\begin{array}{r}10.04 \\
30,289,051 \\
21.27\end{array}$ \\
\hline 全国 & $175,378,301$ & $\begin{array}{r}169,649,935 \\
3.27\end{array}$ & $\begin{array}{r}147,252,010 \\
16.04\end{array}$ \\
\hline
\end{tabular}

2つのCaseについて道路インフラ維持更新コストを推 計した結果を表-2に示寸.

人口が都市地域内，用途地域内，駅勢圈内一集積した Case2の場合, Case1に比べて将来の道路延長は短く, 道 路インフラ維持更新コストは削減できる。しかし，削減

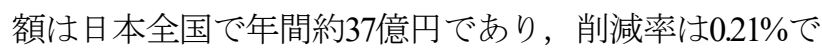
ある. 幅員 $5.5 \mathrm{~m}$ 未満の道路インフラ維持更新コストは地 方都市圈周辺都市において $1.30 \%$ と最も減少している.

ここで，もし仮にメッシュ人口が一定数より少ないメ ッシュにある幅員 $5.5 \mathrm{~m}$ 未満の道路に対して維持更新を実 施しないとした場合について，道路インフラ維持更新コ スト削減額を試算した結果を表-3に示す，都市圈による 分類別にみると, 非都市圈で減少率が大きい。これは, 非都市圈において，人口が少ないメッシュが他の都市圈 による分類よりも多いためである. 全国的に，メッシュ 人口が 0 人のメッシュで幅員 $5.5 \mathrm{~m}$ 未満の道路の維持更新 を実施しないと仮定すると，Case2の3.3\%，573億円の削 減, メッシュ人口が 10 人未満のメッシュで幅員 $5.5 \mathrm{~m}$ 未満 の道路の更新をしないと仮定すると，Case2の $16.0 \%$, 2,813億円の削減となる.

\section{7. 結論}

本研究では日本全国を対象に，3次メッシュを都市圈， 都市地域面積割合, 用途地域面積割合, 最寄り駅からの 距離を用いて地区特性により60に分類し，地区特性と道 
路インフラ量, 道路インフラ維持更新コストとの関係を 分析した. その結果，人口あたり道路インフラ維持更新 コストは地区特性による分類間で最大 16.7 倍の差がある ことを明らかにした。

さらに，自然増減のみを考慮した場合と，人口がコン パクトに集積した場合の地区特性による分類ごとの人口 割合を設定し，道路インフラ維持更新コストを推計した。 その結果, 人口が集積した場合, 地方都市圏周辺都市に おいて幅員 $5.5 \mathrm{~m}$ 未満の道路延長の削減率が最も高く, 全 国的に見ると，道路インフラ維持更新コストは人口が集 積した場合は自然増減のみを考慮した場合より年間約37 億円， $0.21 \%$ 削減することが可能である. また仮に，さ らなる道路インフラ維持更新コストの削減を実現するた めに, メッシュ人口が 10 人未満のメッシュに対しては維 持更新を実施しないとした場合を試算すると，道路イン フラ維持更新コストの削減額は2,813億円で，16.0\%の削 減であることを明らかにした。

なお，本研究では，単位延長あたり道路インフラ維持 更新コストは不変であると仮定して維持更新コストを推 計したが，道路インフラ維持更新コストの削減額は，都 市のコンパクト化による人口の集積だけでは $0.21 \%$ に どまっている．維持更新コストのより一層の削減には, 人口の集積だけでなく, 技術開発による維持更新コスト 原単位の削減が求められる.

\section{参考文献}

1) 佐藤晃, 森本章倫 : 都市コンパクト化の度合に着目 した維持管理費の削減効果に関する研究, 都市計画 論文集，No.44-3，pp.535-540， 2009.

2) 加知範康, 山本哲平, 川添豊, 加藤博和, 林良嗣 : 市街地拡大抑制策評価のための市街地維持コスト推 計システムの開発, 第 36 回土木計画学研究・講演集, 2007.

3) 加知範康, 高木拓実, 加藤博和, 森杉雅史, 林良 嗣: 都市域拡大抑制による市街地維持コストの削減 可能性に関するミクロレベルでの分析, 第 33 回土木 計画学研究・講演集, 2006.

4) 土屋貴佳, 室町泰徳 : 都市のコンパクト化による道 路維持管理費用削減に関する研究, 都市計画論文集, No.41-3, pp.845-850, 2006.

5) 根市政明, 土屋貴佳, 室町泰徳 : 都市のコンパクト 化による都市施設マネジメント費用の変化に関する 研究, 土木計画学研究・論文集, Vol.24, No.1, 2007.

6) 国土交通省国土政策局国土情報課：国土数值情報ダ ウンロードサービス, http://nlftp.mlit.go.jp/ksj/, 2015 年 7 月 29 日閲覧.

7）国土交通省（建設省）：道路統計年報

8）統計情報研究開発センター：地域メッシュ統計

9）社会資本整備審議会：「国際化, 情報化, 高齢化, 人口減少等 21 世紀の新しい潮流に対応した都市再生 のあり方はいかにあるべきか」答申『都市再生ビジ ヨン』, pp.3-4, 38-44, 2003.

10) 道路投資の評価に関する指針検討委員会：道路投資 の評価に関する指針（案），第 2 版，p.98，1999.

(2016. 2. 26 受付)

\title{
A STUDY ON ROAD MAINTENANCE AND RENEWAL COST FOCUSING ON AREA CHARACTERISTICS
}

\author{
Ryoji MATSUNAKA, Tetsuharu OBA, Dai NAKAGAWA, Masaki OKAMOTO, \\ Kazuyuki YONEYAMA and Hirokazu TANAKA
}

In recent years, many studies have made the advantages of compact cities clear. In this study, we classified one kilometer grid cells in Japan into 60 area characteristical categories, and analyzed the relationship between the area characteristics, road length, and road maintenance and renewal cost. As a result, we showed that there is many differences in road maintenance and renewal cost per capita among area characteristical categories. In addition, we estimated future road maintenance and renewal cost in two scenarios. The first, a scenario where population mitigation dose not occur, and a second that assume population concentrated in urban areas. As a result, we showed that road maintenance and renewal cost will be reduced if the population urbanizes, but the rate of reduction is $0.2 \%$. 